UDC 339.97:339.7

JEL Classification: FO2, GO1

DOI: 10.15587/2706-5448.2020.210956

\section{Lutsyshyn Z., Mazur M., Katrych $\mathbf{0}$.}

\title{
ANALYSIS OF THE VULNERABILITY OF THE EXISTING FUNCTIONING PRINCIPLES WITHIN THE WORLD ECONOMY
}

The study focuses on the contemporary realities of globalization trends, the coronary crisis and the principles of the world economy.

The paper examines current trends in the world economy, its ability to respond to the challenges of time under uncertain conditions and adaptability to new realities under the influence of the pandemic «COVID-19». The analysis showed that one of the most problematic areas is the fragility of the Western system of economies, overproduction of capitalism, which reveals the contradictions, paradoxes and main trends of financial, economic, political, social and resource crisis. Here the world's major players behind the curtain of the COVID-19 pandemic are trying to improve their economic positions, get out of the long recession and redistribute economic resources, and reformat the nature and directions of cooperation and integration.

Such general scientific methods as analysis and synthesis in assessing real GDP and debt to GDP in developed countries and developing countries were used to study the world economic system and financial and economic crises. The historical method was also used in the analysis of conceptual approaches and the development of crises in general, the statistical method was used in the analysis of statistical data; structural and factor analysis, extrapolation method. This made it possible not only to carry out a comparative analysis of existing trends, but also to identify bottlenecks in the existing mechanisms of the world economic system. To the problematic areas we refer the significant bubble, the fiction of the Anglo-Saxon model of the world's financial system, the lack of institutions in the world economy and the lack of adequate financial and economic instruments to respond rapidly to pandemics (so-called contingencies) At the same time, it showed a renaissance of the role of the state in a pandemic. Additionally, it provided an opportunity to address the urgency of changing the principles of the current world economic system and to change the philosophy of organization, structure and perception of the world economy as a whole.

Keywords: global economic crisis, COVID-19 pandemic, financial crisis, fragility of the existing economic system.

Received date: 16.04.2020

Accepted date: 22.05.2020

Published date: 31.08 .2020
Copyright (C) 2020, Lutsyshyn Z., Mazur M., Katrych O. This is an open access article under the CC BY license (http://creativecommons.org/licenses/by/4.0)

\section{Introduction}

In the process of the new realities, the current trends of globalization have begun to shift from the local (regional) to the micro-state level in order to give each country a method of tackling isolation in order to curb the spread of the COVID-19 pandemic [1]. Social distance, self-isolation and travel restrictions have led to a reduction in the workforce in all sectors of the economy and the loss of many jobs. Educational institutions were closed, and the demand for goods and products decreased. In contrast, the need for medical expenses has increased significantly. The food sector has also seen an increase in demand due to panic purchases and food stocks. In this scenario, the world is facing an international problem, where globalization as a process of global economic, political, cultural integration and unification, led by «omnipotent» capitalism, has proved powerless in the fight against the pandemic [2]. This situation involves abandoning the traditional tools imposed on society by globalization to address the pandemic. The global economic panic, and later the collapse that en- gulfed all financial markets and the international economy, prompts to make a more comprehensive analysis of the preconditions for the global crisis. Therefore, the object of research is the current realities of globalization trends, the coronary crisis and the principles of the world economy. The aim of research is to determine the principles of the world economy, its fragility, the role of capitalism in this process, by conducting a comprehensive analysis of the conceptual foundations and preconditions for the emergence and development of the crisis under uncertainty and unpredictability.

\section{Research methodology}

The methodological basis of the study were the theoretical developments of world economic thought, the conceptual provisions of modern economic theory, monographic and scientific literature of interdisciplinary direction. Much attention in the last decade has been paid to the fundamental issues of modern global transformations, in which scientists have modeled and predicted the inevitability of 
changes in the existing world order [1-3]. The most nontrivial, comprehensive and noteworthy is the analysis of the change of the existing paradigm of the global organization of the world $[4,5]$, which gave the authors the basis for the hypothesis of changing the nature of transversal relations in the existing world economic system. Issues of fragility of the existing economic system were studied from the standpoint of crisis analysis [6, 7]. In this regard, a prominent place is occupied by research on convergence and divergence, increasing global inequality, asymmetry of global economic development [8-10]. The work on global financial imbalances $[11,12]$ and the anniversary report of the Club of Rome [13] should be singled out. Although with a delay of at least 5 years, the whole range of existing problems of the modern world order was recognized. As for issues related to the problems caused by the COVID-19 pandemic in the economic sphere, the publications related to the coronary crisis are dominated by politics and journalism.

Processes occurring in geoeconomic space and resulting in the breakdown of vertically hierarchical and linearly identifiable [14-16] systems affected by the COVID-19 pandemic are also not considered. The analysis of the revealed problems carried out in this work is carried out from the standpoint of world development the day after tomorrow, taking into account the need to rethink the principles of the world economy, which lie in the plane of relevant global intersystem transformations.

\section{Results of research and discussion}

Over the last decade, there have been serious distortions in the economic cycle. According to the classical theory of economic cycles [17], economic development under capitalism consists of cycles which comprise four phases:

1) decline (recession, crisis);

2) stagnation (stagnation, depression);

3) revival;

4) rise (continuation of the recovery phase from the moment when the pre-crisis level of economic development is reached).

The last crisis was the global financial and economic crisis of 2008-2009. Then came the stagnation (Fig. 1), which previously usually lasted as long as the crisis (recession). However, in 2020 we still have not seen (meaning the world economy as a whole, in some countries, the economic cycle may look different) the transition from the phase of stagnation to the recovery phase.

After analyzing the data in Fig. 1, it is not possible to say that the recovery phase of the world economy has not taken place. Moreover, there are many forecasts that promised a global economic recession in 2020. The world economy has now accumulated more disparities than before the crisis of 2008-2009. It should be noted that the total debt of all sectors of the economy in the United States exceeded $300 \%$ of GDP [19]. Similar debt situation is in other world economic centers the European Union (EU) and China [20]. Key central bank $(\mathrm{CB})$ rates are falling, and billions of new USD/euros/yuans and other currencies are being printed with one explanation: this is needed to combat the effects of the coronavirus pandemic. This simply freed the hands of all central banks to infuse space volumes of money into the economy, which does not help the real economy at all, but only increases debt and inflates the bubble of fictitious capital [21]. Despite such efforts, the world economy is still approaching recession.

Back in 2015, scientists noted that «Meanwhile, against the background of the absence of any alternative models, the conditions for a new crisis are already emerging. Real wages fell or remained at the same level in Japan, Southern Europe, the United States and the United Kingdom. The shadow banking system has been restored, and now it is larger than in 2008» [22]. In today's globalized world, offshore accounts for almost $10 \%$ of world GDP, which amounted to 84.835 trillion USD in 2018. It is possible to assume that there is now much more capital offshore than 2 years ago [23].

The world unemployment rate is constantly falling (Fig. 2). Globalization, the technological transformation of all spheres and the consequent digitization of human capital labour are becoming less and less necessary because the innovations and emerging technologies that drive the economy are coming to the fore. The author of [24] notes «The total global debt of banks, households, companies and countries has grown by 57 trillion USD since the beginning of the crisis and is now almost three times higher than world GDP. The new rules, which require banks to have more reserves, have been relaxed and postponed. And one percent of the population has become even richer».

Thus, it is possible to see (Fig. 2) that after the crisis of 2007-2008 there was a significant downturn in the labor market, and after a slight recovery of the international economy in 2009 began a trend towards global unemployment. This also confirms the fact that the transition from the recovery phase to the growth phase did not take place.

The updated report of the International Monetary Fund (IMF) on the global forecast of economic growth (Fig. 3) indicates a number of reasons for such trends.

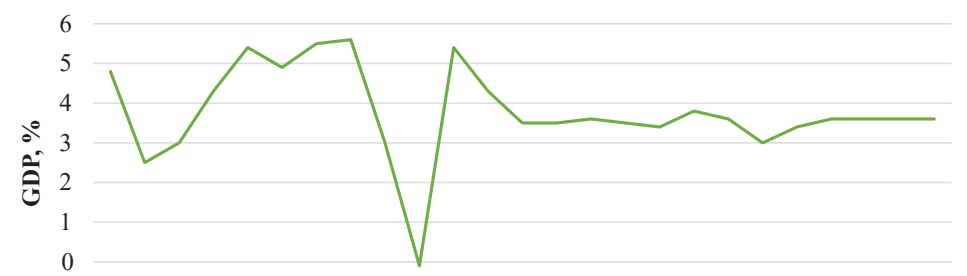

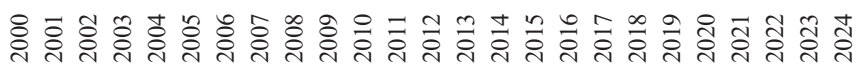
Years

Fig. 1. World real GDP, \% [18]

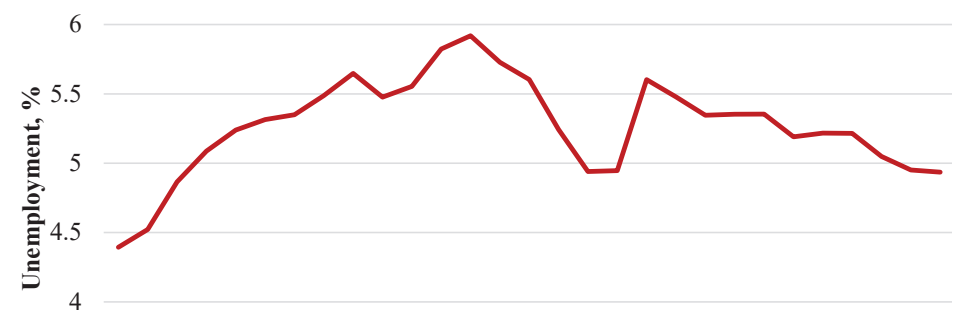

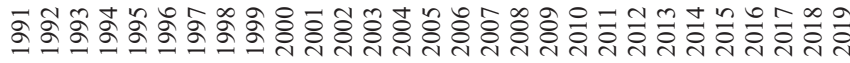
Years

Fig. 2. World unemployment, \% [20] 


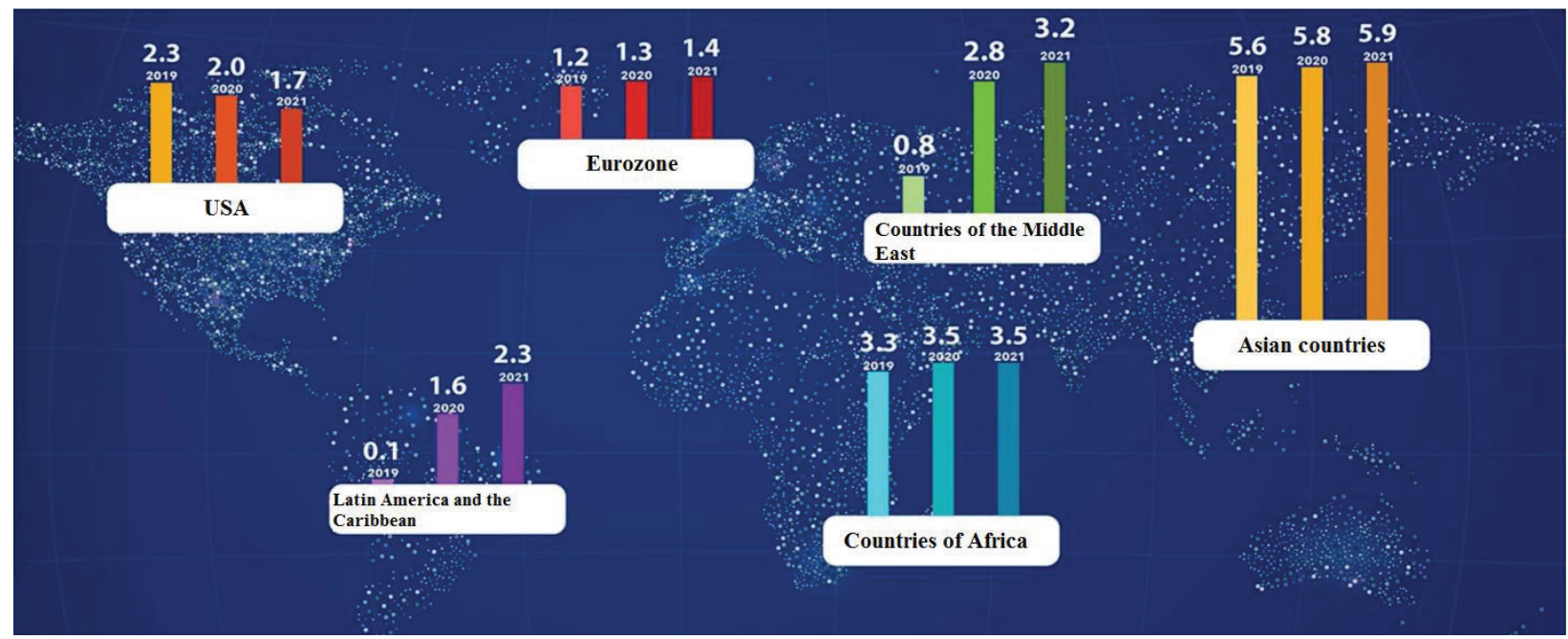

Fig. 3. Economic growth forecast, \% (constructed by the authors on the basis of data [24]

The main factors of influence include Brexit, the decline in production due to the trade war between the United States and China, international migration. Another factor is the lack of large amounts of capital in offshore areas and the frantic growth of public debt due to the development of fictitious capital and in addition to COVID-19 [24] - an interesting scenario for the future development of the world.

Global growth is projected, but rather a slowdown after 2019, namely: $2018-3.6 \%, 2019-2.9 \%, 2020-$ $3.3 \%, 2021-3.4 \%$ (Table 1) and in countries with developed economies will also see a slight slowdown from $1.7 \%$ in 2019 to $1.6 \%$ in 2020 and 2021.

Export-dependent economies such as Germany should benefit from improved external demand, while US economic growth is projected by the IMF to slow when the fiscal stimulus subsides. For emerging markets and developing countries, the IMF forecasts growth from $3.7 \%$ in 2019 to $4.4 \%$ in 2020 and $4.6 \%$ in 2021, a decrease of $0.2 \%$ over all years [24]. The International Monetary Fund, in its report, drew attention to India, where growth slowed sharply due to stress in the non-banking financial sector and weak income growth in rural areas. China's growth was revised by $0.2 \%$ to $6 \%$ growth in 2020 , reflecting the trade agreement with the United States. Overall, risks to the global economy remain declining, despite positive news about trade and reduced concerns about Brexit without an agreement [24]. The IMF warns of new possible trade frictions between the US and the EU, as well as between the US and China. Such developments, along with growing geopolitical risks and social unrest, could change simple financing conditions, expose financially vulnerable sectors and severely disrupt growth, according to an IMF report. Countries need to work together in several areas to boost growth and prosperity $[25,26]$. The IMF insists on the removal of protectionist trade barriers. A new international tax regime is also needed to adapt to the growing digital economy, reduce tax evasion and avoidance, while enabling all countries to receive their fair share of tax revenues, the IMF notes.

Fig. 4 shows a comparison of real GDP and debt to GDP in developed and developing countries.

Analyzing the data in Fig. 4, it can be stated that the gap between the growth of the real sector of the economy and debt is very large, it has only been growing since 2009. At the end of 2019, public and private debt reached 188 billion USD, or $230 \%$ of world GDP.

Economic growth forecast by country

Table 1

\begin{tabular}{|l|c|c|c|c|}
\hline \multicolumn{1}{|c|}{ Country } & 2018 & 2019 & 2020 & 2021 \\
\hline World & 3.6 & 2.9 & 3.3 & 3.4 \\
\hline Developed countries & 2.2 & 1.7 & 1.6 & 1.6 \\
\hline USA & 2.9 & 2.3 & 2.0 & 1.7 \\
\hline Eurozone & 1.9 & 1.2 & 1.3 & 1.4 \\
\hline Germany & 1.5 & 0.5 & 1.1 & 1.4 \\
\hline France & 1.7 & 1.3 & 1.3 & 1.3 \\
\hline Italy & 0.8 & 0.2 & 0.5 & 0.7 \\
\hline Spain & 2.4 & 2.0 & 1.6 & 1.6 \\
\hline Japan & 0.3 & 1.0 & 0.7 & 0.5 \\
\hline United Kingdom & 1.3 & 1.3 & 1.4 & 1.5 \\
\hline Canada & 1.9 & 1.5 & 1.8 & 1.8 \\
\hline Dther countries & 2.6 & 1.5 & 1.9 & 2.4 \\
\hline Developing countries & 4.5 & 3.7 & 4.4 & 4.6 \\
\hline Developing countries, Asia & 6.4 & 5.6 & 5.8 & 5.9 \\
\hline China & 6.6 & 6.1 & 6.0 & 5.8 \\
\hline India & 6.8 & 4.8 & 5.8 & 6.5 \\
\hline ASEAN - 5 & 5.2 & 4.7 & 4.8 & 5.1 \\
\hline Developing countries, Europe & 3.1 & 1.8 & 2.6 & 2.5 \\
\hline Bussian Federation & 2.3 & 1.1 & 1.9 & 2.0 \\
\hline Developing countries, Latin America & 1.1 & 0.1 & 1.6 & 2.3 \\
\hline Brazil & 1.3 & 1.2 & 2.2 & 2.3 \\
\hline Mexico & 2.1 & 0.0 & 1.0 & 1.6 \\
\hline Developing countries, the Middle East & 1.9 & 0.8 & 2.8 & 3.2 \\
\hline Saudi Arabia & 2.4 & 0.2 & 1.9 & 2.2 \\
\hline Developing countries, Africa & 3.2 & 3.3 & 3.5 & 3.5 \\
\hline Nigeria & 1.9 & 2.3 & 2.5 & 2.5 \\
\hline Republic of South Africa & 0.8 & 0.4 & 0.8 & 1.0 \\
\hline Dther countries & 5.0 & 5.0 & 5.1 & 5.1 \\
\hline
\end{tabular}

Note: built by the authors on the basis of data [24] 


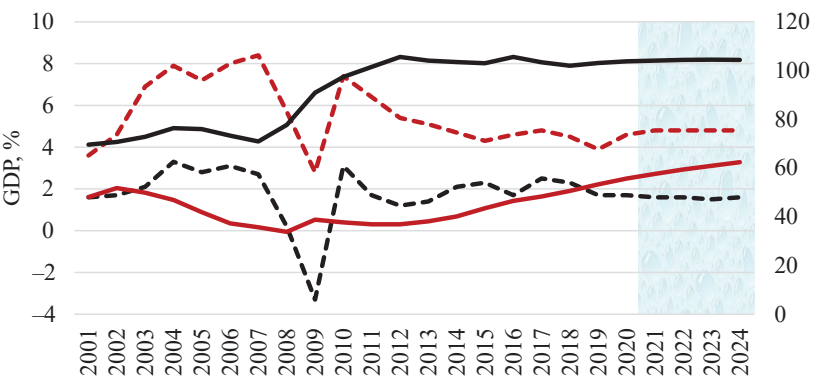

Years

- - Developed countries, real GDP, \%

- - Developing countries, real GDP, $\%$

- Developed countries, debt to GDP, \%

— Developing countries, debt to GDP, \%

Fig. 4. Comparison of real GDP and debt to GDP of developed and developing countries, \% [24]

Accordingly, a logical question arises, how can the economy grow with the constant low growth of Western economies, which is a consequence of declining productivity, aging population, high debt and increased stratification of society?

Another economic paradox may be the share of GDP per capita (in thousands of USD) and productivity (in \%), Fig. 5.

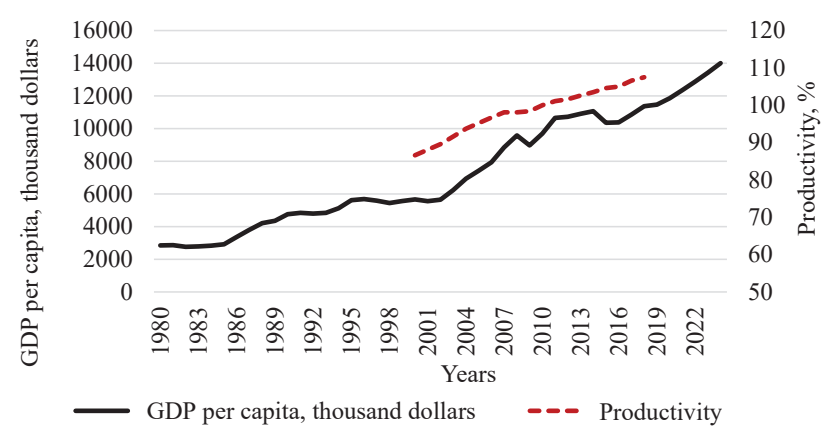

Fig. 5. Comparison of GDP per capita in thousand USD and productivity in \% [27]. Note: from 1980 to 1999 productivity was not calculated, the first calculations began only in the early 2000s, and after 2017 this indicator was no longer used due to its inaccuracy

Analyzing this ratio (Fig. 5), it is possible to note the general trend of growth, which is a positive economic factor for the real sector of the economy as a whole. But in this situation, such a positive trend may occur if all the other economic indicators mentioned above are negative. In recent years, there has been a significant increase in debt, GDP reduction, economic slowdown, and GDP per capita in the world, however, productivity is increasing due to mass unemployment and the payment of social benefits.

At the end of 2019, a disease such as the coronavirus «COVID-19» appeared in the world. However, this disease, like many previous ones such as MERS, EBOLA, SARS, could not be localized in a certain area, region, or continent. COVID-19 has become the world pandemic. Accordingly, to combat the pandemic, all countries were localized and then completely isolated from the rest of the world to ensure that the spread of the coronavirus is contained. Every economy suffers insane losses from the struggle not because it directs all its money and capital to the struggle, but because it supports its economy. Of course, each country now has its own temporary money program from central banks and other government insti- tutions, which is designed to address the unprecedented situation with COVID-19 that each country faces.

The Federal Reserve System (FRS) under the influence of coronavirus will affect economic activity and determine the risks to the economic forecast. In light of these developments, the FRS has reduced the target range for federal funds from 0 to $1 / 4$ percent. The Committee expects to maintain this target range until it is confident that the economy has withstood the latest developments and is on track to achieve its maximum employment and price stability goals [28]. In the coming months, the FRS will increase its portfolio of US government bonds by at least 500 billion USD, and the portfolio of mortgage bonds issued by semi-government agencies Ginnie Mae, Fannie Mae and Freddie Mac by at least 200 billion USD. The FRS current balance sheet includes more than 2.5 trillion USD government bonds and 1.37 trillion USD agency mortgages. Thus, the treasury bond portfolio will grow to more than 3 trillion USD, mortgage securities - up to about 1.6 trillion USD. Thus, the FRS assets will grow from the current 4.3 trillion USD up to 5 trillion USD, a record level (the previous record - 4.52 trillion USD was recorded in January 2015) [28]. This is a return to «quantitative easing» (QE), three rounds of which have been held since 2008. The repurchase of securities from the market is aimed at lowering interest rates in the economy to ensure «the flow of credit to households and companies». The FRS has also changed the terms of its loans to banks directly through a so-called discount window, much like it did during the 2008 crisis. The rate on these loans was reduced by 1.5 basis points at once - more than the key rate - to $0.25 \%$. This is a new historical minimum of the discount rate (even in 2008-2009 it was at a level slightly higher $-0.5 \%$ ) [29]. In addition, as during the crisis of 2008-2009, the FRS extended the term of such loans from one day to 90 days. The FRS sees a potential demand from market participants for such extraordinary borrowings and wants to encourage «more active use of the discount window». In addition, the FRS has decided to reduce reserve requirements for banks (the share of funds that the bank is required to keep in reserve with the FRS) to zero from the current $10 \%$. «This action removes reserve requirements from thousands of financial institutions and will help support lending to households and businesses», the FRS said in a statement.

The European Central Bank (ECB) has announced a new (since March 18, 2020) program «Pandemic Emergency Purchase Program» (PEPP) in addition to 120 billion Euros to support the economy in the fight against COVID-19 in the amount of 750 billion Euros by the end of the year. Together, this is $7.3 \%$ of euro area GDP. The ECB provides liquidity of up to 3 trillion EUR due to refinancing operations, including the lowest interest rate ever offered, $-0.75 \%$. Offering funds below the deposit rate allows increasing the incentive from negative rates and direct it to those who can get the most benefit [30].

In turn, the Bank of England launched in March its new term financing program with additional incentives for small and medium-sized enterprises TFSME (Term Funding scheme with additional incentives for small and medium-sized enterprises). A new term funding scheme with additional incentives for small and medium-sized businesses to fight the COVID-19 coronavirus worth 645 billion has been set up by the end of the year. The program for 
the purchase of non-financial investment grade corporate bonds in the amount of 200 billion pounds was also extended and the bank's rate was reduced by 65 basis points, from $0.75 \%$ to $0.1 \%$ [31].

In addition, the Bank of Japan unanimously decided to increase the upper limit for the purchase of promissory notes and corporate bonds by a total of 2 trillion yen and to conduct purchases with an upper limit exceeding 3.2 trillion yen and approximately 4.2 trillion respectively. These additional purchases will last until the end of September 2020. The bank has also decided to actively buy bonds of Japan's largest companies, which form ETFs and J-REITs, so that their outstanding amounts grow at an annual rate with an upper limit of about 12 trillion yen and about 180 billion yen, respectively [20].

Fig. 6 shows comparisons of inflation in developing countries, developed countries, Switzerland, Britain and the United States. The last three were chosen according to the method - the oldest and most stable currencies in the world.

Analyzing the data (Fig. 6), it is possible to see a trend that inflation in the US and developed countries is almost the same. This suggests that the economies of developed countries are too dependent on the dollar. However, the question arises, if the FRS and many developed countries are printing money and pouring it into their economies to support its growth, for example, as the US FRS is doing, then why is inflation kept at $2.5 \%$ ? Whether it's «fiat» money or inflation somewhere, for example, it could be financing for the IMF, where the United States is the main investor in this financial organization.

Fig. 7 shows the amount of printed money of the Central Bank of the world's leading countries over the past 59 years. It is possible to see that bursts occur in any crisis or in contingencies. An example of contingency is the murder of John Fitzgerald Kennedy.

It was during his reign that a campaign was underway to nationalize a structure such as the FRS, for which considerable sums had to be allocated, and segregation began, which also required significant infusions. All this was also reinforced by the Cold War and the Caribbean crisis. The funds were printed for the 1973-1974 oil crisis and the presidential election, but in 1996-1997, in addition to the presidential election, the annexation of oil countries in the Middle East under the pretext of US nuclear weapons began.

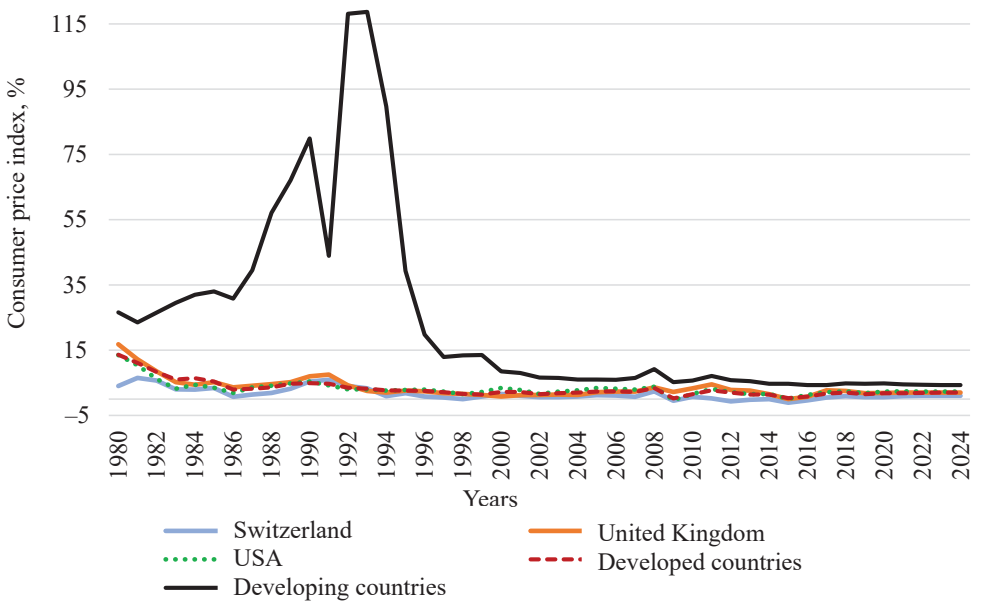

Fig. 6. Comparison of the consumer price index, average in \% [27]

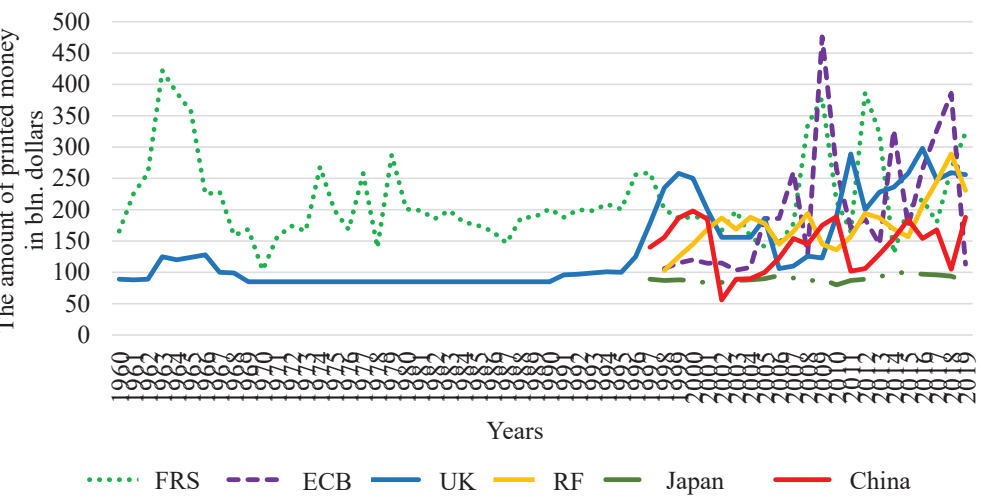

Fig. 7. The amount of money printed in the leading countries in the national currency in billion: FRS - Federal Reserve System (FRS); ECB - European ; RF - Russian Federation; Japan and China in billion USD [27, 30-34]

After the financial and economic crisis of 2007-2008, 2011-2012 were marked as years of laws and restrictions for migrants. The beginning of 2017 signaled a beginning of a new international financial and economic crisis. The FRS actions show the following trend: by printing money on a large scale, the FRS is trying to overcome any crisis. A financial hole is simply filled with a huge amount of money.

When there is a new issue of the dollar, which is not supported by anything at all, it simply inflates the economy with money like drugs, while the real sector of the economy receives nothing at all and does not develop. There is a financial bubble. Fig. 8 shows the amount of money printed by the US Treasury in billions USD in term of their denominations.

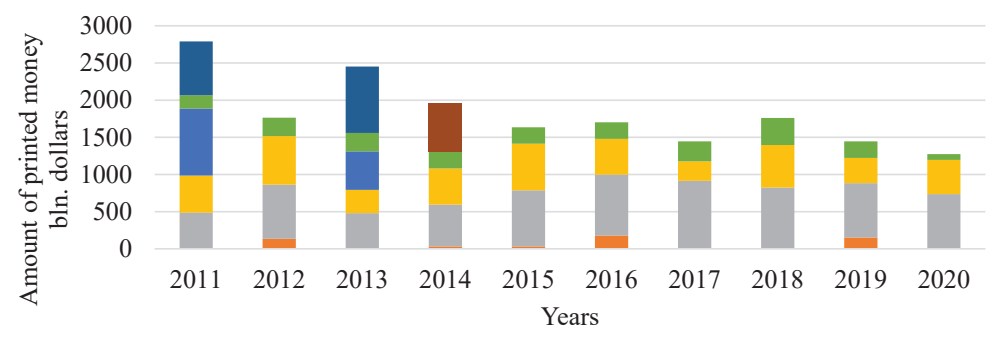

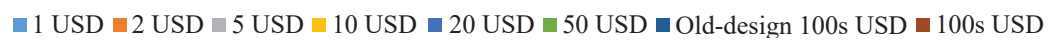

Fig. 8. Amount of printed real money: The US Treasury in billions of USD [27] 
This makes it possible to conclude that the ratio of actually printed and «fiat» money is very different, where the amount of real money is far less than the factious. Reserve in millions of USD, an increase in the total balance of assets can be observed, which grows much faster than the number of real printed money. Similarly, it is possible to see an increase in assets during the financial and economic crisis in 2007-2008, when the money machine was launched. The same situation is happening now under the pretext of fighting COVID-19. The stock market is pumped with «fiat» capital not to destabilize the markets.

This increase in assets suggests that interest rates on US federal funds should decline (Fig. 10) and the yield spread between 5 -year and 30-year bonds (Fig. 11) should approach zero. Due to high demand, bond yields have fallen to a historic low, which is a characteristic of a recession in the economy, and the launch of the printing machine speaks of an extraordinary quantitative easing of the economy. Fig. 9 shows the total number of assets of the US Federal

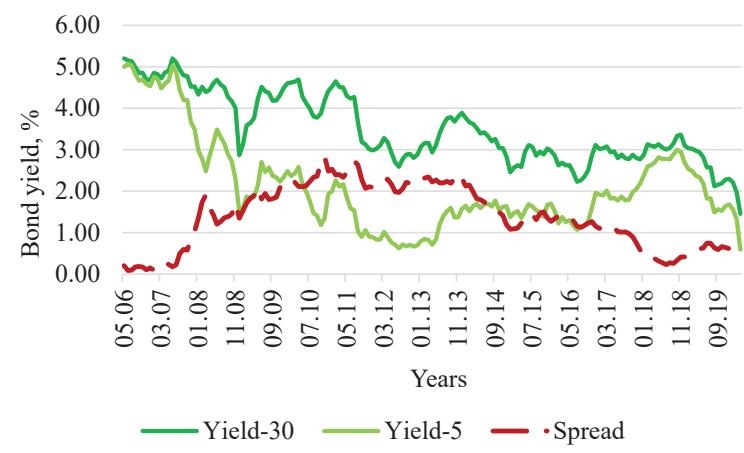

Fig. 11. Bond yield in \% [27]: Yield-30 - 30-year-old; Yield-5 - five-year-old; 5pread (difference between the purchase price and the sale price)

It is followed by Brazil - 64.7 billion USD, France 54.1 billion USD, Great Britain - 51.2 billion USD, Italy 27.8 billion USD, India - 26.4 billion USD, The Russian Federation - 24.6 billion USD, Saudi Arabia - 21 billion USD, South Korea - 13 billion USD, Mexico - 9.9 billion USD, Japan - 5.2 billion USD, Argentina -

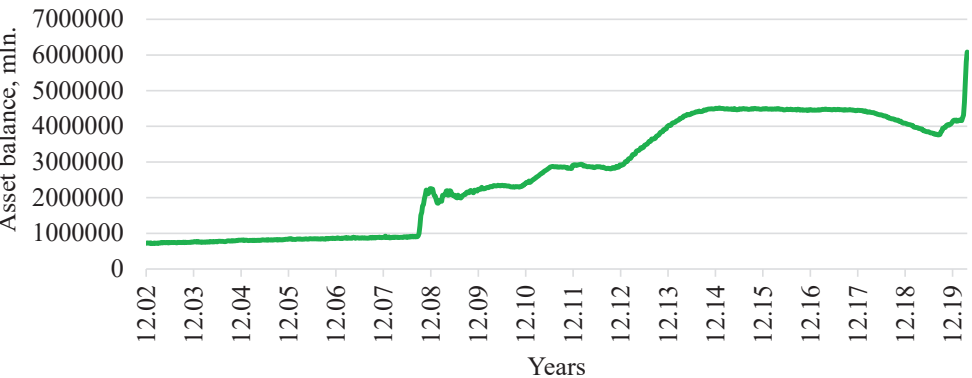

Fig. 9. The total balance of assets of the US Federal Reserve in million USD [27]

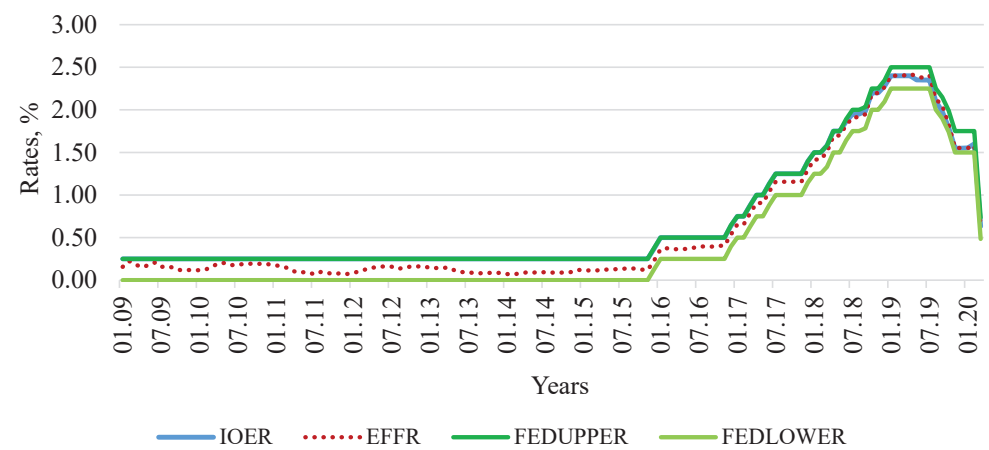

Fig. 10. Rates on federal funds of the US Federal Reserve in \% [27]: IOER - interest rate on excess reserves; EFFR - effective federal funds rate; FEDUPPER - the upper limit of the rate on federal funds; FEDLOWER is the lower limit for federal funds

Thus, having analyzed the world economic situation, mechanisms of interaction, it is possible to conclude that the preconditions for the crisis began much earlier than the spread of the COVID-19 pandemic.

Fig. 11 shows that since 2016, there has been a decline in bond yields long before the pandemic, which led to the sinking of the US economy in recession.

The five G20 countries with the largest coronavirus stimulation programs:

1. US: 2.3 trillion USD (11 \% of GDP).

2. Germany: 189.3 billion USD (4.9\% of GDP).

3. China: 169.7 billion USD (1.2\% of GDP).

4. Canada: 145.4 billion USD (8.4\% of GDP).

5. Australia: 133.5 billion USD (9.7\% of GDP).
4.45 billion USD, and Indonesia -2.2 billion USD [27].

The United States has applied an incentive package of 2.3 trillion USD - the largest in the history of the country. The European Central Bank will spend more than 1 trillion Euros on Eurozone bonds over the next nine months. Canada guaranteed 2,000 USD a month to people affected by the coronavirus outbreak. The coronavirus crisis has become a powerful reminder that the nation's main political and economic unit remains.

After many weeks of blockades, deaths and the closure of much of the world economy, radical uncertainty still remains the best feature. Undoubtedly, the pandemic will lead to a change in political and economic power in such a way that it will become apparent only later.

It was necessary to learn a lesson of resilience from the financial crisis of 2008. An interconnected financial system was created that seemed efficient and may have coped well with small shocks, but it was systemically fragile. Everyone understood this, but as long as it was possible to make good money on it, no one wanted to admit it, despite numerous studies on vulnerability, imperfection, imbalance and instability [35, 36].

Were it not for the massive government bailout, or rather the massive infusion of money, the system would have collapsed when the real estate bubble burst. Apparently, we did not learn this lesson.

\section{Conclusions}

As a result of the study it is concluded the following: - COVID-19 pandemic was not only a litmus test, but also a catalyst for rethinking the modern principles of the world economic system;

- currently radical restructuring requires well-established principles of world functioning, which increasingly demonstrate the inability to meet the challenges of the 
times, and in some, especially in economic terms, development, in the near future into - nowhere. Whereas the principles of capitalism, profitability and superprofitability are offset by the practice of lust and the desire and thirst for material enrichment at any cost and without regard to social and moral issues in many spheres and industries;

- in the field of international financial relations it has led to increased chaos, unpredictability of international capital flows, extremely strained relations between debtors and creditors, and significantly increased the instability of major capital markets;

- it is necessary to change the principles in the approaches to the definition and comparison of fundamental indicators of economic efficiency. It is stable in comparison, economic and statistical analysis, forecasting to take as a basis purely economic indicators: interest rates, data on reserves, interest rate growth, GDP dynamics, etc. However, it is necessary to recognize that in different countries, the definition of GDP is different. It is advisable to either define a unified standard set for calculating GDP, or create something like a financial cross-rate or financial rate of GDP (differentiated conversion factor) [7];

- financial sector needs to be reformed, namely to reduce its «bubbling» and control over self-sufficiency; currency and credit - reducing the level of speculation, inefficient lending, volatility, crisis; correct consideration of the growing sector of virtual finance and digitalization of the economy. Radical reform or reformatting is needed by international financial institutions, which have once again demonstrated their inability to deal with crises; - during the COVID-19 pandemic, there is an opportunity to observe the renaissance of the effective role of the state in solving problems in a pandemic, the socalled contingency or unpredictable conditions. This was accompanied by a clear and rapid isolation/demarcation of countries, a mention of the existence of borders (geographical), which have seemed to be forgotten in the European Union in recent decades;

- coronomic can be considered a transitional phase/stage to restructuring, but rather the reconfiguration of the world economy in the large and long term. From the construction of new transversal connections on P. Hannah's principles of interconnectedness [5] of the world, the reconfiguration of industries (from transformation to the emergence of new and disappearance of some existing ones) to the formation of a new paradigm of world order. The new paradigm should be based on completely different principles with a new philosophy of organization and perception of the economy as a whole. The economic system that will be built after this pandemic must be less short-sighted, more resilient and more sensitive to the fact that economic globalization is far ahead of political globalization. While this is the case, countries will need to strive for a better balance between reaping the benefits of globalization and the required degree of self-sufficiency.

\section{References}

1. Worldometers: COVID-19 pandemic. Available at: https://www. worldometers.info/coronavirus/\#countries

2. Callaway, E. (2020). The race for coronavirus vaccines: a graphical guide. Nature, 580 (7805), 576-577. doi: http://doi.org/ 10.1038/d41586-020-01221-y
3. Bell, D., Inozemtsev, V. (2007). Epokha razobschennosti: Razmyshleniia o mire XXI veka. Moscow: Tsentr issledovaniia postindustrialnogo obschestva, 304.

4. Fukuyama, F. (2014). Political Order and Political Decay: From the Industrial Revolution to the Globalization of Democracy. Farrar, Straus and Giroux, 690.

5. Khanna, P. (2016). Connectography: Mapping the Future of Global Civilization. Random House, 496.

6. Gadzhiev, K. (2010). Mirovoi ekonomicheskii krizis v zerkale sotsiokulturnykh i politiko-kulturnykh transformatsii. Mirovaia ekonomika i mezhdunarodnye otnosheniia, 8, 19-31.

7. Lutsyshyn, Z. O. (2008-2009). Suchasna kryza svitovoho finansovoho rynku - ekonomichna bezpretsedentnist chy strukturni prorakhunky. Naukovyi visnyk Uzhhorodskoho natsionalnoho universytetu. Seriia: Mizhnarodni vidnosyny, 2-3, 10-25.

8. Birdsall, N. (2006). Rising Inequality in the New Global Economy. Voprosy Ekonomiki, 4, 84-89. doi: http://doi.org/10.32609/ 0042-8736-2006-4-84-89

9. Halchynskyi, A. S. (2010). Ekonomichna metodolohiia. Lohika onovlennia. Kyiv: «ADEF-Ukraina», 572.

10. Spence, M. (2012). The Next Convergence: The Future of Economic Growth in a Multispeed World. Picador Paper, 320.

11. Kravchuk, N. Ya. (2012). Dyverhentsiia hlobalnoho rozvytku: suchasna paradyhma formuvannia heofinansovoho prostoru. Kyiv: Znannia, 784

12. Mozghovyi, O. M., Frolova, T. O., Rudenko-Sudarieva, L. V. et. al.; Mozghovyi, O. M. (Ed.) (2017). Hlobalnyi finansovyi rozoytok: tendentsii, tekhnolohii, rehuliuvannia. Kyiv: KNEU, 784.

13. Rimskii klub, iubileinii doklad. Verdikt: «Starii Mir obrechen Novii Mir neizbezhen!» (2018). Available at: https://politcom. org.ua/rimskij-klub-jubilejnyj-doklad-verdik/?fbclid=IwAR35pb Bq1VnLTrwk1dryvECjhaDXmPKHk3TRxgDBGnvsUIIBqbZpuslynww

14. Wallerstein, I. (2001). The End of the World As We Know It Social Science for the Twenty-First Century. Univ Of Minnesota Press, 288.

15. Castells, M. (2000). The Rise of the Network Society (The Information Age: Economy, Society and Culture, Volume 1). Vol. 1. Wiley-Blackwell, 594.

16. Kissinger, H. (2015). World Order. Penguin Books, 432.

17. Marks, K., Engels, F. (1959). K kritike politicheskoi ekonomii. Vol. 13. Moscow: Gosudarstvennoe izdatelstvo politicheskoi literatury, 805.

18. GDP Forecast by Country. Statistics from IMF. 2020-2024. Knoema. Available at: https://knoema.com/tbocwag/gdp-forecast-bycountry-statistics-from-imf-2020-2024?country=United\%20States

19. U.S. House of Representatives. Available at: http://www.house.gov 20. The World Bank. Available at: http://www.worldbank.org

21. Iakovets, Iu. V. (2011). Globalnye ekonomicheskie transformatsii XXI veka. Moscow: Ekonomika, 384.

22. Mason, P. (2017). Postcapitalism: A Guide to Our Future. Farrar, Straus and Giroux, 368

23. Rapoza, K. (2017). Tax Haven Cash Rising, Now Equal To At Least $10 \%$ of World GDP. Forbes. Available at: https://www. forbes.com/sites/kenrapoza/2017/09/15/tax-haven-cash-risingnow-equal-to-at-least-10-of-world-gdp/\#5214d1aa70d

24. Godovoi otchet MVF 2019. Available at: https://www.imf.org/exter$\mathrm{nal} / \mathrm{pubs} / \mathrm{ft} / \mathrm{ar} / 2019 / \mathrm{eng} /$ assets/pdf/imf-annual-report-2019-ru.pdf

25. Kravchuk, N. Ya., Lutsyshyn, Z. O. (2015). Systemni determinanty suchasnykh hravitatsiinykh protsesiv u heoekonomichnomu. Mizhnarodna ekonomichna polityka, 2 (23), 29-49.

26. Lukianenko, D., Poruchnyk, A., Stoliarchuk, Ya. (2010). Hlobalni finansovi dysbalansy ta yikh makroekonomichni naslidky. Zhurnal yevropeiskoi ekonomiky, 9 (1), 73-92.

27. GDP per hour worked. Organisation for Economic Co-operation and Development. Available at: https://data.oecd.org/lprdty/ gdp-per-hour-worked.htm

28. Federal Reserve press release (2020). Board of Governors of the Federal Reserve System. Available at: https://www.federalreserve. gov/monetarypolicy/files/monetary20200315a1.pdf 
29. Federal Reserve Bank of New York. Available at: https://www. newyorkfed.org

30. ECB announces $€ 750$ billion Pandemic Emergency Purchase Programme (PEPP) (2020). European Central Bank. Available at: https://www.ecb.europa.eu/press/pr/date/2020/html/ecb. pr200318_1 3949d6f266.en.html

31. What is quantitative easing? Bank of England. Available at: https:// www.bankofengland.co.uk/monetary-policy/quantitative-easing

32. Bank of Japan. Available at: https://www.boj.or.jp/en/statistics/index.htm/

33. The Central Bank of the Russian Federation. Available at: https:// www.cbr.ru/eng/

34. The People's Bank of China. Available at: http://www.pbc.gov.cn/

35. Lukianenko, D., Mozghovyi, O. (2006). Finansovo-investytsiina asymetriia hlobalnoho ekonomichnoho rozvytku. Rynok tsinnykh paperiv Ukrainy, 11-12, 3-4.

36. Lutsyshyn, Z. O., Kravchuk, N. Ya. (2014). Svitova valiutna systema u poshukakh invariantiv hlobalnoi finansovoi stabilnosti. Aktualni problemy mizhnarodnykh vidnosyn, 121 (II), 33-43.
Lutsyshyn Zoriana, Doctor of Economics, Professor, Deputy Director, Scientific and Methodological Center for Organization of the Educational Process, Taras Shevchenko National University of Kyiv, Ukraine; Professor, Department of International Finance, State Higher Educational Institution «Kyiv National Economic University named after Vadym Hetman», Ukraine, University of Economics and Humanities (WSEH), Poland, e-mail: zoriana7468@gmail.com ORCID: http://orcid.org/0000-0002-3972-5303

Mazur Mykola, Department of International Finance, State Higher Educational Institution «Kyiv National Economic University named after Vadym Hetman», Ukraine, e-mail: k.mazur1997@gmail.com, ORCID: http://orcid.org/0000-0001-8277-0946

Katrych Olena, Department of International Finance, State Higher Educational Institution «Kyiv National Economic University named after Vadym Hetman»,Ukraine, e-mail:elsec1997@gmail.com, ORCID: http:// orcid.org/0000-0002-6022-1118 